\title{
FirST CODIFICATION OF VIETNAMESE BY 17TH-CENTURY MISSIONARIES: THE DESCRIPTION OF TONES AND THE INFLUENCE of Portuguese on Vietnamese orthography*
}

\author{
Gonçalo Fernandes \& Carlos Assunção
}

Universidade de Trás-os-Montes e Alto Douro (Vila Real)

\section{Résumé}

Nous analysons l'importance de la génération des missionnaires jésuites pionniers au service du patronage portugais dans l'implémentation du quốc ngữ [langue nationale] dans l'actuel Vietnam et la description linguistique de la tonologie de la langue annamite ou tonkinoise (anciens noms du vietnamien). Nous étudions, en particulier, le manuscrit Manuductio ad Linguam Tunckinensem (ca. 1745 [avant 1623]) de Francisco de Pina, S.J. (1585 / 1586-1625), et le Dictionarium Annamiticum Lusitanum et Latinum et le traité grammatical Annamiticae seu Tunchinensis Brevis Declaratio (Rome 1651) de Alexandre de Rhodes, S.J. (1593-1660). Nous affirmons que Pina fut, en effet, le premier à utiliser le système de romanisation du Tonkinois, et nous confirmons qu'il fut aussi le premier à décrire en détail ses six tons. Rhodes a approfondi le savoir de Pina, qui est particulièrement explicite dans la description de la tonologie tonkinoise. Nous démontrons aussi que Rhodes a utilisé les dictionnaires manuscrits disparus de Gaspar do Amaral, S.J. (1594-1646) et António Barbosa, S.J. (1594-1647), qui sont d'une importance capitale dans l'utilisation de l'archigraphème « portugais » $<\mathrm{nh}>$ pour représenter le phonème $/ \mathrm{n} /$.

Mots-clés

histoire de la linguistique, linguistique missionnaire, vietnamien, annamite, tonkinois, quốc ngữ

\section{Abstract}

We analyse the importance of the generation of Jesuit pioneer missionaries at the service of the Portuguese Patronage for the implementation of quốc ngữ [national language] in present-day Vietnam and the linguistic description of the tonology of Annamese or Tonkinese (former names of Vietnamese). We analyse, in particular, the manuscript Manuductio ad Linguam Tunckinensem (ca. 1745 [ante 1623]) by Francisco de Pina, S.J. (1585/1586-1625), and the Dictionarium Annamiticum Lusitanum et Latinum and the grammatical treatise Linguae Annamiticae seu Tunchinensis Brevis Declaratio (Rome 1651) by Alexandre de Rhodes, S.J. (1593-1660). We corroborate that Pina was indeed the first to use the Romanization system of Tonkinese, and we establish that he was also the first to describe its six tones in detail. Rhodes expanded Pina's knowledge, which is particularly explicit in the description of Tonkinese tonology. We also explain that Rhodes used lost manuscript dictionaries written by Gaspar do Amaral, S.J. (1594-1646) and António Barbosa, S.J. (1594-1647), which is evident mainly in the use of the "Portuguese" digraph $<\mathrm{nh}>$ to represent the phoneme $/ \mathrm{n} /$.

\section{Keywords}

history of linguistics, missionary linguistics, Vietnamese, Annamese, Tonkinese, Quốc ngữ

* We'd like to dedicate this paper to Prof. Roland Jacques for his contributions to the historical studies on the relationships between Vietnam and the missionaries from the Portuguese Patronage. We'd also like to gratefully acknowledge the help of Dr. Nguyễn Vũ Thu Hà (Khoa Bồ Đào Nha of Đại học Hà Nội) for her improvements on the description of Vietnamese tones, and the editorial board and the anonymous referees whose stimulating comments and recommendations we have tried to implement in the final version of this paper. 


\section{INTRODUCTION}

We analyze the work of the first pioneer missionaries of the Portuguese Patronage in Vietnam in the first half of the 17th century and their metalinguistic texts. The paper is structured as follows: first, we describe the historical background of the Portuguese discoveries, the constitution of the Portuguese Patronage or the Ius Patronatus [Right of Patronage] given by various papal bulls and their importance for the evangelization of South East Asia, particularly Macau, which became the center of Christianity in China, Japan and nearby territories, although it was "only" a Vice-Province. Then, we will describe the activities of pioneer missionaries at the service of the Portuguese Patronage, mainly the Portuguese Jesuits Francisco de Pina, S.J. (1585/1586-1625), Gaspar do Amaral, S.J. (1594-1646) and António Barbosa, S.J. (1594-1647), and the French Jesuit Alexandre de Rhodes, S.J. (1593-1660). We describe the first published metalinguistic works on Vietnamese, i.e., the Dictionarium Annamiticum Lusitanum et Latinum and the Linguae Annamiticae seu Tunchinensis Brevis Declaratio (Rome 1651) by Alexandre de Rhodes and their main sources. This chapter is divided into two sections. In the first section, we will analyze the implementation of the Romanization system called currently Quốc ngũu [national language] and Portuguese orthography in Vietnamese, namely the representation of the phoneme $/ \mathrm{n} /$ by the Portuguese digraph $<$ nh $>$. In the second section we will explicitly analyze the influence of Francisco de Pina in de Rhodes's description of the six Tonkinese tones, comparing Pina's manuscript Manuductio ad linguam Tunchinensem (ca. 1745 [ante 1623]) and de Rhodes's Linguae Annamiticae seu Tunchinensis Brevis Declaratio (Rome 1651).

\section{HISTORICAL BACKGROUND ${ }^{1}$}

The treaties of Tordesillas (June 7, 1494) and Zaragoza (April 22, 1529), signed by the Portuguese and Spanish kings, regulated the spheres of influence or parts of the world of Portuguese and Spanish colonization / evangelization, in the west and the east, respectively. Both countries divided the world in two, mutatis mutandis, similar parts, the lands between the meridian 370 leagues west of the Cabo Verde islands (ca. $46^{\text {th }}$ meridian west) and the antemeridian 297.5 leagues east of the Moluccas Islands (ca. $142^{\text {nd }}$ meridian east) belonging to Portugal. In addition, for Catholic countries like Portugal and Spain, the Pope's authorization to colonize

1 We used some data from an earlier paper concerning mainly the historical context, the presentation of the first missionaries of Portuguese patronage in Vietnam and the description of the first Vietnamese metalinguistic texts (see FERNANDES \& AssunÇão 2014). 
was indispensable because the main official reason was the conversion of native or "infidel" people to the Catholic religion.

In effect, after 1452, with the papal bull Dum Diversas (June 8, 1452) and, mainly, the Romanus Pontifex (January 8, 1455), Pope Nicholas V (1397-1455) gave Portuguese king D. Afonso V (1432-1481) the Ius Patronatus [Right of Patronage] and complete jurisdiction of overseas lands, discovered and still to be discovered (See, v.g., Rego 1940, p. 7-8, Jacques 1999: 43-52). These rights (and obligations) consisted in the exclusive supervision of the administration and missionary activity in overseas territories, the establishment of dioceses and parishes, the nomination of bishops and ecclesiastical benefits, the funding of the clergy (secular and regular) and the construction and provision of churches, schools and convents, etc. (Sena 2014, p. 91-92).

The Portuguese missionaries - or those at the service of the Portuguese Patronage - did not initially know the native languages. They took translators with them, interpreters or "linguas" as they were known. Thus, one of their first missionary tasks was to learn the native languages and write catechisms, conversational booklets, dictionaries and grammars, in order to communicate with local inhabitants and to teach the forthcoming missionaries.

This was particularly important after the establishment of the Society of Jesus (1540) by Pope Paul III (1468-1549), the Council of Trent (1545-1563) and, especially for Asia, the first five Provincial Councils of Goa in India (1567, 1575, 1585, 1592 and 1606), which left deep marks on the religious and social evolution of the Portuguese empire in Asia (Souza 2008, p. 424). The main objective was the adequacy of the rules of the Council of Trent or the Counter-Reformation to Eastern realities. One of the recommendations, for example, of the third Provincial Council of Goa (1585) was the publication of catechisms in Portuguese and in native languages in order to disseminate better the Catholic faith (Faria 2013, p. 227; see also Fonseca 2006, p. 87).

The arrival of the Portuguese in China, Japan and Vietnam occurred mutatis mutandis in the middle of the sixteenth century (see, v.g., Jacques 1999). The enormous diocese of Goa (India), erected by the papal bull Romani pontificis circumspectio (January 31, 1533) of Clement VII (1478-1534), covered the jurisdiction of the whole East, i.e., from the Cape of Good Hope (Cape Town in South Africa) to China and Japan. In 1558, Pope Paul IV (1476-1559) established the Diocese of Malacca (Malaysia) by the apostolic constitution Pro Excellent! Praeminentia (February 4), and, 18 years later, Pope Gregory XIII (1502-1585) established the diocese of Macau (China) by the bull Super specula militantis Ecclesiae (January 23, 1576), all suffragan to the Archdiocese of Goa (see Fernandes \& Assunção 2014). 
Macau became a Portuguese colony in 1557 (see, v.g., Correia 2012), received a Charter from king D. Filipe I of Portugal (Filipe II of Spain) (1527-1598) in 1586 and was the center of Christianity in China, Japan and nearby territories. This was the situation at least until about the end of the 17 th century with the establishment by Pope Alexander VIII (1610-1691) of the Diocese of Nanjing by the apostolic constitution Pontificis Sollicitudo and the reestablishment of the Diocese of Beijing (China) by the apostolic constitution Romanus Pontifex, Beati Petri (April 10, 1690) (see Teixeira 1996, p. 15-16). The Portuguese Patronage of the Orient ended with the integration of Macau into the People's Republic of China on December 19, 1999.

The Portuguese arrived in present-day Vietnam in mid-September 1516, in the region of Chăm Pa (in contemporary central and southern Vietnam) (see, v.g., Manguin 1972, p. 1-3; 45-46). The initial contacts had not been planned and resulted from a storm that forced the boats to change course, and the official "discovery" of "Cochinchina" by the Portuguese occurred seven years later, in 1523. Despite the fact that the Portuguese never conquered Vietnam, their presence there lasted for more than three centuries, with many casual relationships (see, v.g., Manguin 1972 , p. 1-3; 236), mainly through the evangelization organized by missionaries from the Portuguese Patronage. In the 17 th century, the country was divided mutatis mutandis by the 18th parallel north into two main kingdoms: Tonkin, namely northern Vietnam, with the capital set in Thăng Long (nowadays Hà Nội), and Annam / Cochinchina, which corresponds to central and southern Vietnam, with the capital set in Phú Xuân (Huế). After the secession war, in 1614, the Trịnh dynasty ruled the Kingdom of Tonkin and the Nguyễn family the Kingdom of Annam or Cochinchina. Vietnam was called internally Đại Việt, but, externally, in their relations with China, they used the toponym An Nam, which was called "Cochin-China" by the Portuguese (see, v.g., Jacques 2004, p. 56-58).

\section{First Missionaries of Portuguese Patronage in Vietnam}

The first book which describes the first contacts between the Portuguese and Vietnam was written by the chronicler and grammarian João de Barros (14961570). It was entitled Terceira decada da Asia: Dos feytos, que os Portugueses fizeram no Descobrimento \& conquista dos mares \& terras do Oriente (Lisbon 1563). Barros states that the Viceroy of India, Afonso de Albuquerque (1453-1515), sent Fernão Peres de Andrade (1458-1552), a sailor, merchant and diplomat, to explore the coast of China and to establish the first contacts with the Chinese. He left Malaca on 12 August 1516, but he was forced to change course because of a storm and they arrived in the Kingdom of Chăm $\mathrm{Pa}$, in Cochinchina. Fernão Peres de 
Andrade set foot ashore to look for fresh water and could report on the quality of life of the inhabitants. After the first impression, Fernão Peres ordered that the sailors offer gifts to the local population, trying to soften potential conflicts and establish relationships with the natives. Fernão Peres continued his expedition but he couldn't go to China. He stopped at the island of Côn Sơn, on the southern coast of Vietnam, belonging to the current Côn Đảo archipelago, in Southern Vietnam, in the South China Sea. Côn Sơn was named "Pullo Condor" by the Portuguese, from the Malayan language "Pu Lao Kundur". Côn Sơn or Pullo Condor was not inhabited at that time but it was well known by sailors because of the quantity of fresh water, chickens, birds, turtles and many species of fish available (Barros 1563 , f. 42r-43v).

Another of the first Portuguese texts about Vietnam was written by the Dominican friar Gaspar da Cruz, O.P. (ca. 1520-1570), and it was entitled Tratado em que se contam muito por extenso as cousas da China (Évora 1570). It is the first European book specifically about China. Gaspar da Cruz was a missionary in Malacca and he decided to travel to China to know that famous kingdom better. In his trip, he landed in the kingdom of Cochinchina to obtain fresh water and take a break. He describes it as a great kingdom, with a lot of people and rich citizens. Specifically, he says that Cochinchina confines southwards with China, with approximately a hundred leagues along the seacoast. He also observed that Cochinchina was subjected to the king of China and that the people looked very much like Chinese people and dressed in the same way. Unfortunately, he did not make any linguistic description of Vietnamese, but he mentioned the fact that the letters of the language of Cochinchina were similar to those of Chinese, even though it was a very different language. For him, Vietnamese and Chinese people understood each other only in writing and not orally because China had many different languages, and its inhabitants could not understand each other (Cruz 1569, f. b iiir; for other details, see Fernandes \& Assunção 2014, p. 9-10).

Roland Jacques, O.M.I, presently Emeritus Professor of Saint Paul University in Ottawa and Vicar Provincial of Vietnam from the Congregation of the Missionary Oblates of Mary Immaculate, is a French scholar who has studied in detail the relationships between Vietnam and the missionaries from the Portuguese Patronage. He discusses, when studying the generation of pioneers of the first organized ${ }^{2}$ mission, the Jesuit missionaries at the service of the Portuguese Patronage between 1623 and 1678 with particular emphasis on Francisco de Pina, S.J. (1585/1586-1625), Gaspar do Amaral, S.J. (1594-1646), António Barbosa, S.J. (1594-1647) and Alexandre de Rhodes, S.J. (1593-1660) (see Jacques 2012, p. 43-48).

2 For the first unorganized missions in Vietnam see, v.g., Jacques 1999, p. 126-141. 
Francisco de Pina was born in Guarda, in northern Portugal between 1585 and 1586. He entered the Society of Jesus at 19 and spent several years studying at the College of Madre de Deus in Macau, where he was a student of Father João Rodrigues "Tçuzu" (1562-1633) and was able to make use of his language skills. He arrived in Vietnam at Chăm Pa (Hội An, known as "Faïfo" among the Portuguese) in 1617 and passed away tragically only eight years later (December $15,1625)$ at only 40 years old while trying to rescue passengers in danger in Đà Nẵng ("Turam" or "Turão" for the Portuguese), a port on the Hàn river on the south central coast of Vietnam (Jacques 2002, p. 24-27; See also Mourão 2005, p. 317-319).

Gaspar do Amaral was born in Corvaceira, district of Viseu, in the north of Portugal in 1594; he was ordained priest of the Society of Jesus in 1622, and, in the following year, he left for a mission in Japan, having initially remained in Macau at the College of Madre de Deus. He was sent to Tonkin in 1629 by the Rector of the College of Macau, Father Pedro Morejón (ca. 1562-1639), because "he had not heard news of the missionaries" (Ribeiro 2001, p. 68). Gaspar do Amaral was Rector of the College of Macau and Vice-Provincial of the Jesuit Japanese Province (1641-1645) (Wernz, Schmitt \& Goetstouwers 1950, p. 650). He died in a shipwreck in front of the island of Hainan in southern China (February 26, 1646) at approximately 52 years old (Mourão 32005 , p. 310-313, 2012, p. 54-61).

António Barbosa was born in Arrifana do Sousa, Penafiel, district of Porto, also in the north of Portugal, in 1594. He entered the Society of Jesus in 1624, and he traveled to Goa and Macau and collaborated with Gaspar do Amaral for the Portuguese version of the Annamese dictionary (Zwartjes 2011, p. 291). In 1635, he taught at the College of Macau, and, between 1636 and 1642, he remained in Tonkin. In 1644 there was news from his stay in Macau (Mourão 2012, p. 59, footnote 16); he felt ill and, therefore, "was sent for a cure to Goa, where he died in 1647 (Jacques 2002, p. 30, footnote 36).

Alexandre de Rhodes was born in 1593 in Avignon, in the south of France, in a family of Jewish origin. His ancestors came from Calatayud, in Aragon near Zaragoza, in Spain, "had escaped the Iberian persecutions and, changing their name from Rueda ${ }^{4}$, had settled in Avignon" (Maryks 2010, p. 151). Rhodes hid his Jewish and Spanish origins when he entered the seminary of Saint Andrew's

3 Isabel Mourão presented her Ph.D in 2011 at the École Pratique des Hautes Études, Section des Sciences Historiques et Philologiques, in Paris, under the supervision of Dejanirah Silva Couto, about Amaral's works, entitled Gaspar do Amaral S.J. (1594-1646): La vie et l'œuvre d'un jésuite portugais fondateur de la mission jésuite du Tun Kim à la cour des Trinh. Unfortunately, this work is still unavailable, even in the Library of the French University. The author told us in a personal email that she intends to publish the book soon.

4 "Rueda, written as Rode in Provençal (...), means a small wheel, which the Jews were required to wear on their clothes during the Middle Ages." (Phan 1998, p. 39) 
at the Quirinal in Rome, in 1612, to achieve the novitiate of the Society of Jesus. However, he considered himself French, as he said explicitly in the book Divers Voyages: "ma chere patrie" (de Rhodes 1653, f. ẽ ii v., "Epistre à la Reyne"). He "requested to be admitted into the Roman province rather than that of Lyon because its members were better placed to obtain the permission of the king of Portugal to go to the mission in India" (Phan 1998, p. 39). Rhodes received the Ordination in 1618 and, in the same year, left as a missionary for the Far East. He came to Lisbon by land, where he took the "Santa Teresa", the ship of the Portuguese Patronage, and reached Goa the next year. According to Fidel González Fernández (2011), his missionary activity can be divided into three different periods: 1) between 1619 and 1645 in the Far East at the service of the Portuguese Patronage; 2) between 1645 and 1655 in Europe, mainly in France and Italy, and 3) between 1655 and 1660 in Persia mutatis mutandis current Iran, where he died in 1660, aged 67 years. Alexandre de Rhodes wanted to follow the route of Saint Francisco Xavier, S.J. (1506-1552), but, due to the persecutions in Japan after 1614, Rhodes was forced to stay in Goa for two and a half years and dedicated his time to learning local languages; he arrived in Malacca in 1622 and in Macau in 1623; there he was appointed at the College of Madre de Deus, where he started studying Chinese and Japanese. His first mission in Cochinchina, in Chiêm Thành (Chăm Pa), began a year later in 1624. There he met Francisco de Pina, with whom he started learning the Vietnamese language. However, a year later, Pina drowned in a shipwreck at Đà Nẵng (González Fernández 2011, p. 283). Rhodes still remained some years in Tonkin and in the Nghệ An Province on the north central coast, where he met Gaspar do Amaral. In 1630, during the first reign (1619-1642) of Lê Thần Tông (1607-1662), the ruler Trịnh Tráng (1577-1654) considered the Catholic religion dangerous and started persecuting the Christians (Brockey 2009: 338339). Rhodes was expelled from Tonkin, and he had to retreat to Macau until 1640, where he could still have known father João Rodrigues “Tçuzu”, S.J. (1562-1633) and reinforced the relations with Gaspar do Amaral, S.J. (1594-1646). Rhodes returned to Cochinchina, but, during the Trịnh-Nguyễn War (1627-1673)5 , he was condemned to death (by beheading) in Phú Xuân (Huế) in central Vietnam by the ruler Nguyễn Phúc Tần (1620-1687). He was accused of being a spy for the king of Tonkin, Lê Thần Tông (1607-1662). However, the death sentence would be commuted to perpetual exile. Thus, he boarded a Portuguese ship in Hội An, on the south central coast, on July 3, 1645, never to return to Vietnam (González Fernández 2011, p. 288).

5 Concerning the history of Vietnam, of Catholicism in Vietnam, of the Trịnh (1545-1787) and Nguyễn Lords (1558-1777) and their complicated relationships with one another and with Portuguese missionaries, see, e.g., Manguin 1972, 1984; Taylor \& Whitmore 1995; Phan Khoang 2001; Guillemin 2014; and Fernandes \& Assunção 2014. 
It is also important to mention the first prominent linguist of Japanese, the Portuguese priest João Rodrigues “Tçuzu”, S.J. (1562-1633)', notwithstanding he had never been in Vietnam. His stay in Macau between 1614 and 1633 would change Vietnamese linguistics, due mainly to the further action of his younger colleague and disciple Francisco de Pina. To sum up, João Rodrigues wrote a completely original work, added many linguistic innovations and created a pioneering metalanguage derived from his knowledge of Japanese society and classical Japanese literature. He was the first to describe Japanese in Latin characters, and his descriptions of Japanese address forms, the use of honorifics, hierarchical relations in Japanese society and social differences between men and women are particularly relevant (Zwartjes 2011, p. 94-142; see also Rodrigues 1604 [-1608], 1993 [1620]). Father João Rodrigues ${ }^{7}$ deserves, effectively, as Zwartjes (2011, p. 141) says, to "be classified among the five best Jesuit grammarians from the colonial period", mainly for his Arte da lingoa de Iapam (Nagasaki 1604-1608). Roland Jacques (2012: 44) calls him "un génie de la linguistique" and Charles Ralph Boxer (1904-2000), "the Father of Japanese Language Studies" (Boxer 1950, p. 363). About his main grammar (1604-08), Richard L. Spear says that it "is by any standards the greatest grammatical study of Japanese made during the Christian Century" (Spear 1975, p. 2).

\section{The FiRst VIETNAMESE METALINGUISTIC TEXTS PUBLISHED ${ }^{8}$}

The first published metalinguistic works of Vietnamese are the Dictionarium Annamiticum Lusitanum et Latinum and the Linguae Annamiticae seu Tunchinensis Brevis Declaratio by Alexandre de Rhodes. They were printed by Propaganda Fide (Rome 1651) six years after he had left Vietnam. Therefore, he could not have

6 João Rodrigues was born in Sernancelhe in the district of Viseu in the north of Portugal; he entered the Society of Jesus at the age of fifteen and dedicated almost all his life to evangelization in Japan and China until his death, which occurred in Macau (China). He was a confidant and an interpreter of the Japanese daimyos Toyotomi Hideyoshi (15931598) and Tokugawa Ieyasu (1542-1616), who gave him the nickname "Tçuzu", meaning "translator" or "interpreter". However, when the Japanese started persecuting and expelling the Christians from Japan in 1614, João Rodrigues, after more than 30 years dedicated to the Japanese language and culture, started living in several Chinese cities, but Macau was, effectively, the center of his missionary activity during the last 19 years of his life (Zwartjes 2011, p. 95).

7 Regarding to João Rodrigues' works, see also, e.g., Boxer 1950 and Maruyama 2004 and 2006.

8 We have adopted the following transcription criteria:a) We have maintained the original distinction between uppercase and lowercase graphemes.

b) We have separated the words that were improperly joined, and we have combined those that are separated.

c) We have kept the original punctuation in order not to change the thought or expression of the authors.

d) We have corrected the very clear errors from the original text, even when there are not in the errata. 
ended them there and he probably took with him the manuscripts by Gaspar do Amaral and António Barbosa that he used to compile the dictionary, as we will see.

The Dictionarium has, in whole, 591 pages. The dictionary itself has 450 pages, divided into 900 columns, which Rhodes called pages or sheets; it follows an explanatory appendix, an erratum in Annamese, Portuguese and Latin and an index of words with Latin entries ([440]-[490]). On the other hand, the Linguae Annamiticae seu Tunchinensis Brevis Declaratio is (a sketch of) a grammatical treatise of Annamese, collated, in some copies, at the beginning of the dictionary and in other cases at the end. It has 31 (autonomous) pages, in which Rhodes analyzes Annamese or Tonkinese grammatical issues, such as the letters and syllables $(2-7)$, the accents and other diacritics (8-10), nouns (10-14), "honorific" pronouns (14-20), other pronouns (21-23), verbs (23-26), other indeclinable parts of speech (26-29) and some syntactical precepts (29-31).

The prologue of the dictionary, "Ad lectorem" [to the reader] (6-7), is very enlightening concerning Rhodes's main sources and his explanation of what the Annamese or Tonkinese language is. These details were particularly important for the future European missionaries who would be its potential readers. For example, Rhodes explains that Annamese or Tonkinese was spoken not only in these two kingdoms, Tonkin and Annam (Cochinchina), but was also used as a common language or lingua franca in the neighboring kingdoms of Cao Bằng (nowadays the northeast of Vietnam), Chăm Pa (in central and southern Vietnam), Cambodia, Laos and Siam (Thailand) (de Rhodes 1651a, p. [VI]).

Rhodes also mentions that he spent twelve years listening to local people and, furthermore, he started learning the language with the Portuguese Jesuit Francisco de Pina, who, according to him, mastered Annamese and the first among the Jesuits to know it deeply and preach without any interpreter:

In hoc autem opere praeter ea quae ab ipsis indigenis didici per duodecim ferme annos quibus in illis regionibus tam Cocincinae quam Tunkini sum commoratus,

e) We have eliminated the Latin pedagogic accents.

f) In Latin, we have substituted the ramist letters $<_{\mathrm{v}}>$ and $<\mathrm{j}>$ for $<\mathrm{u}>$ and $<\mathrm{i}>$, and the long (medial or descending) $<\beta>$ for the short (terminal or round) $<$ s $>$. In Portuguese, we have maintained the grapheme $<\mathrm{u}>$ with the value of the consonant $<\mathrm{v}>$.

g) We have put in italics the examples in Portuguese, Vietnamese and Japanese.

h) We have expanded all Latin abbreviations and brevigraphs. We have interpreted the abbreviation "i." (in small and capital letters) as the Latin explicative expression "id est", even in Portuguese texts. It was a common expression amongst Jesuit Latin grammars, which is often mistaken for the grapheme $<\mathrm{L}>$. Some authors have wrongly interpreted this abbreviation for the disjunctive conjunction "vel". However, this conjunction always appears without abbreviation.

i) In Portuguese quotations, we have also expanded the abbreviations, such as $<\tilde{a}>(<a m>$ or $<$ an $>),<\tilde{\mathrm{e}}>(<\mathrm{em}>$ or $<$ en $>),<\tilde{\mathrm{o}}>(<\mathrm{on}>),<\tilde{\mathrm{u}}>(<\mathrm{um}>$ or $<\mathrm{un}>),<\tilde{\mathrm{q}}>(<\mathrm{que}>)$ and the ampersand $\langle \&>(<\mathrm{e}>)$. However, we have maintained the indefinite articles / pronouns $<$ hũa $>$, $<$ algũa(s) $>$ and $<$ nenhũa $>$, in order to preserve a Portuguese phonetic specificity, which still remains in some Northern Portuguese villages. 
ab initio magistrum linguae audiens Patrem Franciscum de Pina lusitanum e nostra minima Societate IESV, qui primus e Nostris linguam illam apprime calluit, et primus sine interprete concionari eo idiomate caepit (de Rhodes 1651, [VI-VII]).

[However, in this work, besides what I have learned from the natives themselves during the almost twelve years I have lived in those regions in Annam and also in Tonkin, I have included what I have heard from the beginning of father Francisco de Pina, a Portuguese from our smallest Society of Jesus, who was the first among us to have extensive knowledge of that language and who first started preaching in that tongue without an interpreter.]

This encomium is repeated in Divers Voyages, where Rhodes declares Pina's great expertise in Annamese:

Nous partimes de Macao au mois de Decembre de cette année 1624. et dix-neufjours, nous arrivâmes tous en la Cochinchine, pleins du desir d'y bien travailler: Nous y rencontrâmes le Pere Pina qui s'estoit rendu sçavant en la langue du païs entierement differente de la Chinoise. (de Rhodes 1653, p. 71-72)

In addition, in the prologue of the Dictionary, Rhodes also adds that he used the works of two other priests from the Society of Jesus, the Portuguese Jesuits Gaspar do Amaral and António Barbosa. They had composed Annamese-Portuguese (Gaspar do Amaral) and Portuguese-Annamese dictionaries (António Barbosa), though the dictionaries were unfinished due to their premature death. Rhodes explains that he developed them and added the Latin version through his own authorship (de Rhodes 1651a, p. [VII]). Michel Ferlus (1982, p. 85), among others, had already determined that Rhodes's dictionary was a compilation of pre-existing works.

\section{Adoption of the Latin alphabet and Portuguese orthography}

In a copy of a letter to the Visitor of the Japanese and Chinese Provinces, possibly written in 1623, Francisco de Pina says that he had already made a little treatise using Annamese-Tonkinese orthography and tonality and that he was starting the redaction of a grammar book. He also says that he was writing in Portuguese characters in order that "we" (Portuguese and / or Jesuits) could read it and know it by heart:

Eu já tenho feito hum Tratadozinho sobre a orthografia e toadas desta lingua, vou entrando pela Arte (...) eu escrevilas [em] letra portuguesa, e para os nossos poderem lelas, aprendendo de cor (Pina ca. 1745b [ca. 1623], f. 414v).

[I have already made a little treatise about the orthography and tonalities of this language. I began with the grammar... I wrote them in Portuguese script so that our brothers can read them, learning by heart.] 
In this quotation, Pina used mutatis mutandis reasons analogous to those of João Rodrigues "Tçuzu" in the Arte da Lingoa de Iapam:

No escreuer esta lingoa em nossa letra seguimos principalmente a ortographia latina, e a Portuguesa, assi por ter a pronunciação de Iapão semelhança com a Portuguesa em algũas syllabas como sam, cha, chi, cho, chu, nha, nho, nhu, et cetera. Como tambem por que Iapão em os Padres e irmãos entre si usam da lingoa e ortographia Portuguesa. (Rodrigues 1604[-1608], f. 55v)

[Writing this language [Japanese] in our script, we mainly followed Latin orthography and Portuguese because of the Japanese language's pronunciation similarity with Portuguese in some syllables, including cha, chi, cho, chu, $n h a, n h o, n h u$, etc., and also because, in Japan, the priests and brothers use the Portuguese language and orthography between themselves.]

João Rodrigues, in the Arte Breve, wrote, a few years before Pina's letter, that he had mainly followed Latin orthography because all Jesuits knew it. He also said that he needed to use Portuguese because it had many phonetic similarities with Japanese and less with Italian and Spanish:

E por que a latina he commum a todas as naçoens, essa seguimos em geral, e o que falta à latina tomamos, ou do Portugues, que tem muitas syllabas semelhantes às Iapoas, que algũas terras de Europa nam tem, ou do Italiano, ou finalmente do Castelhano (Rodrigues 1993 [1620], f. 6r, p. 367).

[And, because Latin is common to all nations, we follow that [language] in general, and what is missing in Latin, we take from Portuguese, which has many similar syllables to Japanese. This is not so for the other languages in the lands of Europe, for example Italian or Spanish.]

It is possible that Pina, in the letter, was referring to the Manuductio ad Linguam Tunckinensem [Handbook of Tonkinese language], of which a copy from the 18th century exists in the Biblioteca da Ajuda (Lisbon, Portugal) and a facsimile was published by Jacques (2002, p. 146-167). Roland Jacques attributes its authorship to the Swiss citizen Honufer Bürgin, in Portuguese Onofre Borges (16141664). However, Jacques's arguments are not totally conclusive. The influence of Portuguese phonetics is evident in the whole manuscript, Rhodes couldn't have access to a document written approximately 15 years after he had left Vietnam and Pina's letter says explicitly that he had made a treatise about Vietnamese tonalities. In addition, Jacques believes that Pina's "tratadozinho" [little treatise] influenced Bürgin's Manuductio (see Jacques 2002, p. 31-39). Thus, until the discovery of new data, we still believe that Rhodes's main source was indeed Francisco de Pina and the Manuductio ad Linguam Tunckinensem was written by him.

The Manuductio is, in fact, a grammatical sketch or a little treatise of the Annamese or Tonkinese language. It has 22 pages, three main chapters (about the tones (accents), the letters of the alphabet and the nouns) and some complementary notes (dialogues, common phrases, some familiar offensive expressions and 
sentences with a possible obscene meaning). It is a copy written approximately in 1745 by Brother João Álvares, S.J. (?-post 1762) in Macau at the Madre de Deus College, which was sent approximately in 1747 to the Japanese Province Procurature in Lisbon with other copies of important Jesuit documents (Rodrigues 1931-1950, t. 4, p. 162).

In recent years, mainly after Roland Jacques's research (2002, 2004, 2012), it seems to be consensual amongst international scholars that Francisco de Pina was the real creator of the Romanization (Latin-based orthography) of the Vietnamese language, which is currently called Quốc ngữ, meaning "national language" (see also Guillemin 2014). Its official introduction in Vietnamese administrative applications occurred only in 1898 by a Decree of the Governor-General of French Indochina (and future president of France) Paul Doumer (1857-1932). However, its application only became definitive in 1909 and, finally, a 1917 imperial edict abolished the traditional method of teaching in favor of an education based on quốc ngữ and French (see Jacques 2004, p. 24, footnote 3). After the independence (September 2, 1945) and the unification (April 30, 1975), quốc ngữ remained the official script in Vietnam (see Thompson 1987).

In conclusion, despite all the convenience provided to future European missionaries, Francisco de Pina was clearly influenced by Father João Rodrigues "Tçuzu", as in the case of Japanese. Gaspar do Amaral, António Barbosa and Alexandre de Rhodes had developed and improved the method. Recently, for example, Otto Zwartjes (2011: 291) and Fidel González Fernández (2011, p. 299) recognized that Rhodes's writings were based on former Portuguese missionaries' works.

On the other hand, Thompson noted that there were many Portuguese influences in Rhodes's dictionary, but he did not understand why it happened:

What is perhaps most puzzling is that Alexandre de Rhodes, who was responsible for the basic codification, was a native of Avignon in southern France, yet the writing system probably shows more oddities relating to Portuguese than to any other one language. In this connection, it is significant that de Rhodes' dictionary included specifically Portuguese-besides the expected Latin-rather than French. (Thompson 1987, p. 55)

His explanation was based only on Portuguese trading and shipping interests in that region and not in the action of earlier missionaries:

Throughout this early period it was the Portuguese trading and shipping interests that represented the most considerable European commitments in the area, and as a result Portuguese was likely enough the most widely used European language of the time. (Thompson 1987, p. 55)

We cannot assess, unfortunately, the degree of influence that Gaspar do Amaral and António Barbosa had on Rhodes because their works have never been printed, and their manuscripts are still lost. In addition to Rhodes's telling that he used the 
dictionaries of Amaral and Barbosa, there are some Jesuit annual letters (annuae litterae) which confirm that they were indeed working on these dictionaries (see, v.g., Rodrigues 1917, p. 360; 1931-1950, t. 3, vol. 2, p. 157; Boxer 2002, vol. 1, p. 189). Given that Gaspar do Amaral died the year following Rhodes' expulsion from Vietnam, it is possible that he had already copied the Portuguese and Vietnamese versions, finishing his Latin translation in Europe. However, there are undoubtedly characteristics of Portuguese authorships.

In addition to the fact that the word "Portuguese" is repeated more than 70 times - "portugueses", 6 times; "lusitani" "dicunt" or "vocant", 29 times; "a" or "pro" "lusitanis", 24 times; "lusitana" "lingua", 5 times; "apud" "lusitanos", 3 times, etc. - there is a specifically Portuguese orthography: the dorso-palatal nasal phoneme represented by the symbol $/ \mathfrak{n} /$ from the International Phonetic Alphabet, is written by the Portuguese digraph $<\mathrm{nh}>$ and not by the Italian or French archigrapheme $<$ gn $>9$. Rhodes says it explicitly but he does not declare that is a specific Portuguese orthography: “(...). adhibemus etiam simul cum, n, vt nhà, domus, \& facit idem quod apud Italos, gna" (de Rhodes 1651b, p. 4) [we also add $[h]$ with $n$, like "nhà", house, and does the same like the Italian "gna"]. This "Portuguese" orthographic mark is still in use in current Vietnamese, such as, for instance, "nhà" [house], "quạnh" [be solitary, deserted], "lành-lạnh" [be a bit cold], "mình" [oneself], "nhẹ" [be light, in weight], "nhè-nhẹ" [be rather light in weight], "nhô" [be small], "nhưng" [but, however] (see, e.g., Michaud, Ferlus, Nguyễn 2015; Haudricourt 2010; Thompson 1987).

Rhodes learnt several languages, and he certainly spoke Portuguese very well, the common language amongst the missionaries from the Portuguese patronage, together with Latin. However, he wrote only in Latin and French (see Rhodes 1653). Thus, Gaspar do Amaral and António Barbosa were exclusively responsible for the adoption of the digraph $<\mathrm{nh}>$ (and not by the Italian or French archigrapheme $<\mathrm{gn}>$ ) for the Vietnamese phoneme $/ \mathrm{n} /$.

\section{Description of tonality}

Pina's influence on Rhodes was not only in the use of the Romanization system but also in the description of Tonkinese tonality. It should be mentioned, however, that Pina and Rhodes didn't distinguish between the Tonkinese language/dialect in northern Cochinchina and Annamese in southern Cochinchina ${ }^{10}$. For both authors, the language was mutatis mutandis the same, although Rhodes's Dictionarium can

9 For the historical orthography of the archigrapheme $<$ gn $>$ in French, see, v.g., Catach 1995, p. 1138-1140.

10 For the analysis of historical Vietnamese dialectology and the tone differences in the two largest Vietnamese cities, Hanoi and Hồ Chí Minh City (Saigon), see, v.g., Maspero 1912 and Michaud, Ferlus \& Nguyễn 2015. 
be considered a mixture of various Vietnamese dialects (see, e.g., Maspero 1912). Michel Ferlus states that Rhodes based his dictionary on the variety spoken in Central Vietnam: "Le Dictionarium Annamiticum Lusitanum et Latinum du Père Alexandre de Rhodes (1651), rédigé dans la romanisation qui deviendra le quốc $n g \tilde{u}$ (...) semble élaboré à partir d'un parler du centre" (Ferlus 1982, p. 85).

However, Maspero tells that Rhodes's Dictionarium and Brevis Declaratio "se rapportent au dialecte tonkinois" (Maspero 1912, p. 9, note 1). In effect, on the one hand, Francisco de Pina and Alexandre de Rhodes explain that this language and its tones can be described with the same characters as the European languages, i.e., in Latin letters. Pinas's Manuductio says that he should start by explaining the Latin alphabet, following the tradition, but, for him, the learning of tonality (or the "accents", in his terminology) is much more important:

Mos est alias in tradendis, discendisque linguis ab alphabeto seu litteris initium ducendi, quem utique morem tenuissem, nisi accentuum notitia ad meliorem litterarum intelligentia hac in lingua praeprimis esset necessaria. (Pina ca. 1745a [ante 1623], f. 313r)

[The custom elsewhere in language teaching and learning is starting with the alphabet or letters. I would have undoubtedly followed this custom if the knowledge of accents were not the prime necessity to a better understanding of the letters in this language.]

Duo tamen praecipue sunt in hoc idiomate notanda, e quibus tanquam fundamentis tota ratio bene addiscendae huius linguae pendet, ita ut sine illis a nostratibus haec lingua vix teneri possit; si uti enim homo constat ex corpore et anima, sic etiam hoc idioma constat ex characteribus quibus a nobis conscribitur, et ex tonis seu accentibus quibus notatur et pronunciatur: quibus duobus prius explicatis et positis tanquam fundamentis, de partibus Orationis, et praeceptis in ipsa oratione seruandis agendum postea. (de Rhodes 1651 b, p. 1).

[Instead, principally, two [fundamental aspects] should be noted in this language, according to the bases of learning this language are based on, as, without them, this language can hardly be comprehended by us; actually, as man is made of body and soul, this language also is constituted by the characters that are described by us and by the tones and accents by which it is pronounced. These two previously explained fundamentals, the parts of speech, and the precepts regarding each phrase will be observed later.]

On the other hand, both describe the six Tonkinese ${ }^{11}$ tones ("de accentibus") similarly. Nguyễn and Edmondson, who didn't know Pina's work, write that

[...] the first documented phonetician of Vietnamese, Alexandre de Rhodes (1651) [...] described them in the following impressionistic terms: "acuteangry" (săc), "smooth-rising" (hỏi), "level" (ngang), "chesty-raised" (ngã),

11 Nowadays scholars consider that Tonkinese maintains the six tones (see, v.g., Nguyễn \& Edmondson 1998, p. 7-8) and the Annamese has the realization of only five tones. The hỏ $i$ and $n g \tilde{a}$ tones have been merged in some provinces of Central Vietnam (see, v.g., Nguyên 1997, p. 26). 
“chesty-heavy" (nặng), "grave-lowering" (huyền) [...]. Three and one half centuries later these characterizations still remain remarkably apt and insightful. (Nguyễn \& Edmondson 1998, p. 2)

Sometimes Rhodes uses the same words as Pina, and occasionally they add different details. In the introduction, Rhodes compares the tones with Greek accents (acute, grave and circumflex) and also the iota subscript diacritic from ancient Greek. Pina is more succinct, giving these details in the description of each specific tone:

Accentus hac in lingua seu tonorum mutationes sunt sex, ex quibus solis multoties significationum diuersitas sumi debet; unde patet huiusmodi tonos ex arte callendi necessitas [esse]. (Pina ca. 1745a [ante 1623], f. 313r)

[In this language there are six accents or tone changes, on which often depend the diversity of significations. It is, therefore, clear that it is necessary to learn the correct pronunciation of these tones.]

Diximus accentus esse quasi animam uocabulorum in hoc idiomate, atque ideo summa diligentia sunt addiscendi. Vtimur ergo triplici accentu linguae Graecae, acuto, graui, et circunflexo, qui quia non sufficiunt, addimus iota subscriptum, et signum interrogationis nostrae; nam toni omnes huius linguae ad sex classes reducuntur, ita ut omnes prorsus dictiones huius idiomatis ad aliquam ex his sex classibus seu tonis pertineant, nulla uoce prorsus excepta (de Rhodes 1651b, p. 8);

[We have said that the accents are almost the soul of the words in this language, and, therefore, the greatest care must be taken with them. Therefore, we use three accents of the Greek language, acute, grave and circumflex, to which, because they are not sufficient, we add an iota subscript and a question mark; however, all tones of this language are reduced to six classes, so all the words of this language pertain to some of these six classes or tones, and no word is, in fact, an exception.]

Furthermore, both explain each tone separately. Francisco de Pina adds each tone's music score, in the key of G, with half (minim) and quarter (crotchet) notes. Pina's explanations are clearer than Rhodes's. Actually, the first tone is the neutral tone, without any voice inflexion, and both authors begin with the same sentence:

Primus tonus esta aequalis, et sine ulla vocis inflexione pronuntiatur, habeturque tum, quando vox aliqua nullo ex quinque signis ; ', , ?, ', : hoc ultimum vocalibus tantum subscribitur ut apud Graecos jota subscritum, notatur. Sunt quidem et alia signa, sed quia non ad vocis inflexionem, verum ad literarum certam pronunciationem dignoscendam adiiciuntur [...].

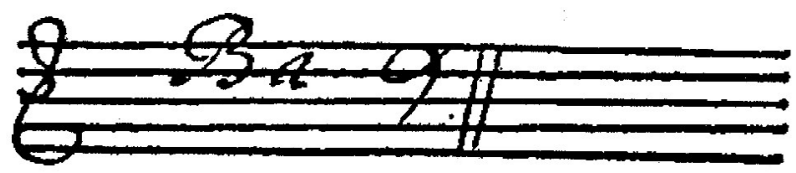

(Pina ca. 1745a [ante 1623], f. 313r). 
[The first tone is equal and is pronounced without any inflexion of voice as it is implied when none of the five signs are used '; , , ?, ', . The latter is written under words using the Greek iota subscript. There are also other diacritic signs, which do not affect the inflexion of the voice but they are used to distinguish the different pronunciation of the letters to which they are added...]

Primus igitur tonus est aequalis, qui sine ulla vocis inflexione pronunciatur, ut $b a$, tres: quod ita verum est, ut etiam si quis aliquem interroget per vocem, chang, quae est aequalis, ut có chang, est ne; nullo modo debeat inflectere vocem interrogando, quia vox interrogativa, chang, nullo notatur accentu, quod si inflecteretur vocis tonus, tunc esset alia significatio: voces itaque quae hunc aequalem habent tonum, nullo notantur accentu; et hoc est sufficiens illarum distinctivum signum, cum omnes aliae suum accentum habeant. (de Rhodes 1651 b, p. 8)

[Therefore, the first tone is equal. It is pronounced without any inflexion of voice. Examples include $b a$, "three"; this is so true that if anyone asks someone else something using the word chăng, which is equal, like có chăng, "it is not", which in no way should inflect the voice in the interrogation because the interrogative word chăng takes no tone. If the tone of the voice is inflected, it will have another meaning; thus, the words that have this same tone are distinguished by having no accent, and this is a sufficient distinctive sign to distinguish them from all the others that have their accents.]

In the description of the other tones, Rhodes's text is almost the same as Pina's, and both always use as an example the word (monosyllable) "ba", which has different meanings according to each specific tone. On the other hand, they find a similarity in Portuguese (Greek, in Rhodes's perspective) accents (acute, grave and circumflex) in order to explain the second, third and fourth tones:

Secundus est acutus: hic profertur voce acuta et quasi iram demonstrante, ut in eadem voce $B a ́$ : concubina Regis vel Principis viri.

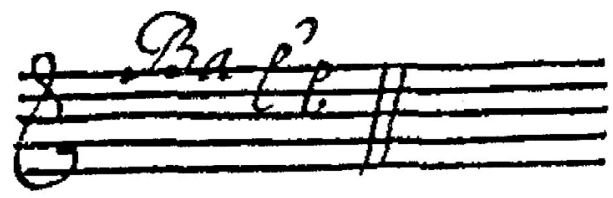

(Pina ca. 1745a [ante 1623], f. 313v).

[The second is acute, which is pronounced with an acute voice and by demonstrating a sound almost like anger, as in the word Bá: "the King's concubine", or "the Prince's sons".]

Secundus tonus est acutus, qui profertur acuendo vocem, et proferendo dictionem, ac si quis iram demonstraret, ut bá concubina Regis, vel principis alicuius viri. (de Rhodes 1651b, p. 8);

[The second tone is acute, which is pronounced by highlighting the voice and pronouncing the word as if someone expressed anger, as in bá, "the King's concubine", or "a Prince's sons".] 
Tertius est gravis, et profertur deprimendo vocem; ut iterum in voce Bà: avia aut Domina usuvenit.

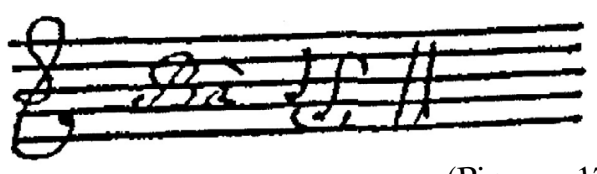

(Pina ca. 1745a [ante 1623], f. 313v).

[The third is grave, and it is pronounced by lowering the voice, as is commonly used again in the voice for $b \grave{a}$, "grandmother" or "lady".]

Tertius est gravis, et profertur deprimendo vocem, ut bà, avia, vel Domina. (de Rhodes 1651b, p. 8);

[The third is grave, and it is pronounced by lowering the voice, as in bà "grandmother" or "lady".]

Quartus est circumflexus, qui exprimitur inflectendo vocem ex imo pectore prolatam et postea sonore elevatam: ut fit in voce $\beta \tilde{a}^{12}$ : colaphus.

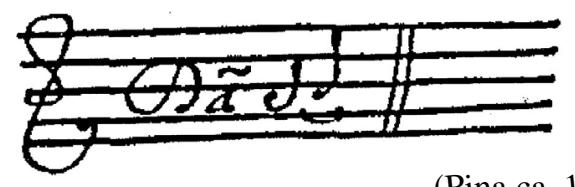

(Pina ca. 1745a [ante 1623], f. 313v).

[The fourth is circumflex, which is expressed by inflecting the voice pronounced from the depths of the chest and then elevating the sound loudly, as is done in the voice vã, "slap".]

Quartus est circumflexus, qui exprimitur inflectendo vocem ex imo pectore prolatam, et postea sonore elevatam, ut $\beta \tilde{a}$, colaphus, vel colaphizare. (de Rhodes 1651b: 8);

[The fourth is circumflex, which is expressed by inflecting the voice pronounced from the depths of the chest and then elevating the sound loudly, as in vã, "the slap" or "to slap".]

The fifth is a lower and descendent tone and is marked by the Greek iota subscript:

Quintus vocatur ponderosus seu onerosus, quia cum quodam pondere, seu onere ex imo pectore prolata voce exprimitur: ut in voce Bą: res derelicta.

12 Interestingly, they used the Greek letter $\langle\beta>$ to represent the voiced labiodental fricative consonant $[\mathrm{v}]$. 


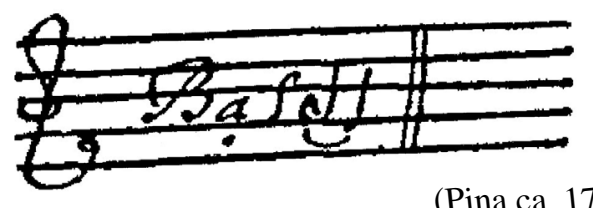

(Pina ca. 1745a [ante 1623], f. 313v).

[The fifth is called ponderous or onerous because it is pronounced by emitting the voice from the depths of the chest and giving a certain force, as in the word $B a$, "derelict thing" (without owner).]

Quintus vocatur ponderosus seu onerosus quia cum quodam pondere seu onere ex imo pectore prolata voce exprimitur, et notatur cum iota subscripto ut bạ res derelicta. (de Rhodes 1651b, p. 8)

[The fifth is called ponderous or onerous because it is pronounced by emitting the voice from the depths of the chest and giving a certain force, and it is noted with an iota subscript, as in $b a$, "derelict thing".]

The last one is a soft tone, but with an interrogative accent, as if someone was asking something:

Sextus denique dicitur lenis, quia leniter profertur, et per modum interrogantis v.g. itáne? Ut in voce Bả: sericum quoddam coloris lutei seu crocei.

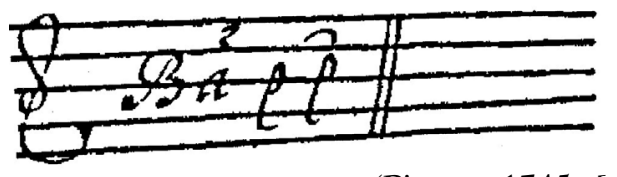

(Pina ca. 1745a [ante 1623], f. 313v-314r).

[Finally, the sixth is called lenient because it is pronounced softly and per interrogative mode, e.g., itáne?, as in the word bả, "a yellow or saffron Tonkinese silk".]

Sextus denique dicitur lenis, quia cum leni quadam vocis inflexione profertur, sicuti cum interrogare solemus, itane? et similia; et idcirco signo illo interrogativo pro accentu notatur ut, bả, quoddam sericum apud Tunchinenses coloris lutei vel crocei. (de Rhodes 1651b, p. 9);

[Finally, the sixth is called lenient because it is pronounced with a gentle inflection of the voice, as when we usually ask, itáne?, and similar questions; therefore, it is noted by an interrogative accent sign, as in $b a \mathfrak{a}$, "a yellow or saffron Tonkinese silk".]

As we have seen, Francisco de Pina represents each tone on a music score, and this is not done by Rhodes. However, he compares Annamese tones to the six musical notes of the diatonic scale C-D-E-F-G-A ("dò", "rẹ”", "mî”, "pha”, "sổ", "lá"), although he is not so clear as Pina: 
Hos autem sex accentus ad nostrae musicae tonos sic accommodare possumus ut aliquam cum illa, uideantur habere proportionem per has uoces ut, dò, pedica: re, radix, in pronunciatione cuiusdam Prouinciae; mĩ, nomen cuiusdam familiae; fa, uel pha, miscere; sổ, cathalogus; lá, folium; ita ut ex his uocibus etiam in lingua Tunchinica significatiuis, per sex tonos linguae Tunchinensis, dò, rẹ, mĩ, pha, sổ, lá, possimus referre aliquo modo sex tonos nostrae musicae, non tamen ita exacte, quin magna intersit differentia; quare nullus istos tonos addiscere poterit, nisi ab aliquo qui linguam bene calleat, illos per se ipsum audierit saepius, ut illis assuescat: Quinque igitur sunt accentuum notae quia tonus equalis non indiget nota [...]. (de Rhodes 1651 b, p. 19)

[Nevertheless, we can, therefore, align these six accents with our musical tones, as they seem to have some kind of proportion in terms of these sounds. Examples are dò, "trap"; rễ, "root" in the pronunciation of a certain province; mĩ, the name of a specific family; fa or pha, "to mix"; sổ, "catalogue"; lá, "leaf"; thus, as these sounds are also meaningful in the Tonkinese language, using the six tones of the Tonkinese language, dò, rễ, $m \tilde{l}, p h a$, sổ, lá, we can refer, in some way, to the six tones of our music, although not exactly, which makes a big difference; because nobody will be able to learn these tones, except someone who is well versed in the language and heard them more often and has become familiarized with them; therefore, there are five music notes because an equal tone doesn't need a note...]

\section{CONCLUSION}

The first descriptions of Vietnam from a western perspective date back to the sixteenth century and belong to chronicler and grammarian João de Barros (14961570) in 1563 and the Dominican Gaspar da Cruz (ca. 1520-1570) in 1570. However, the first linguistic descriptions were due to the group that Roland Jacques called the Jesuit Pioneers, especially the Portuguese Jesuits Francisco de Pina, S.J. (1585 / 1586-1625), Gaspar do Amaral, S.J. (1594-1646) and António Barbosa, S.J. (1594-1647) and the French Jesuit Alexandre de Rhodes, S.J. (1593-1660).

It is nowadays established that it was Francisco de Pina who first described the Annamese or Tonkinese language in Latin characters or using the Romanization system (called today Quốc ngữ, national language, by Vietnamese people) influenced by the Portuguese João Rodrigues "Tçuzu", S.J. (1562-1633). Gaspar do Amaral, António Barbosa and Alexandre de Rhodes developed and improved this method. Rhodes also used two manuscript dictionaries written by Amaral and Barbosa and left an identity mark of Portuguese orthography (currently also of Vietnamese): the digraph $<\mathrm{nh}>$ representing the dorso-palatal nasal phoneme $/ \mathrm{n} /$.

On the other hand, Francisco de Pina was also an important source for Rhodes' description of Tonkinese tones. On this particular point, the similarities between the texts of Rhodes's Linguae Annamiticae seu Tunchinensis Brevis Declaratio (Rome 1651) and Pina's Manuductio ad linguam Tunchinensem (ante 1623) are quite impressive. They complement each other, but Pina's text is clearer, because 
he explains each tone with the help of a music score, in the key of G, with half (minim) and quarter (crotchet) notes. Both explain the six Tonkinese tones using the same scripts as European languages and they describe them with very similar words.

To sum up, for Pina and Rhodes, the six Tonkinese tones can be described as follows: the first one is a neutral tone, without any voice inflexion (the ngang tone); the second one is an acute-angry tone, pronounced with an acute voice, revealing a sound almost like anger (the sắc tone); the third one is a grave tone, pronounced by lowering the voice (the huyền tone); the fourth one is a chesty-raised tone, inflecting the voice pronounced from the depths of the chest and then elevating the sound loudly (the ngã tone); the fifth one is a chesty-heavy tone, pronounced by emitting the voice from the depths of the chest and giving a certain force (the nặng tone); and, at last, the sixth one is a question tone, pronounced with a gentle inflection of the voice, like in an interrogative sentence, as if someone was asking something (the hỏi tone).

Finally, the quotation of Nguyễn and Edmondson (1998, p. 2) must be revised, adding Pina's name to Rhodes's: these characterizations by the first phoneticians of Vietnamese, Francisco de Pina and Alexandre de Rhodes, "three and one half centuries later [...] still remain remarkably apt and insightful".

\section{REFERENCES}

Barros, João de, 1563. Terceira decada da Asia: Dos feytos, que os Portugueses fizeram no Descobrimento \& conquista dos mares \& terras do Oriente, Lisboa, João Barreira. Online: http://www.archive.org/details/terceiradecadada00barr (last access: 24 July 2016)

Boxer, Charles Ralph, 1950. « Padre João Rodrigues Tçuzu S.J. and his Japanese grammars of 1604 and $1620 »$, Boletim de Filologia 11, 338-363.

- 2002. Opera Minora, 3 vols, Lisboa, Fundação Oriente.

Brockey, Liam M., 2009. Journey to the East: The Jesuit Mission to China, 1579-1724, Cambridge, Mass., Harvard University Press.

Catach, Nina (dir.), 1995. Dictionnaire historique de l'orthographe française, Paris, Larousse.

Correia, Pedro Lage Reis, 2012. « La Compagnie de Jésus à Macao et en Asie Orientale: la transmission du christianisme dans les 'espaces de frontières' ( $\mathrm{XVI}^{\mathrm{e}}$ siècle) », Hugues Didier \& Madalena Larcher (ed.), Pédagogies Missionnaires: Traduire, transmettre, transculturer, 32e Colloque du CÉDRIC, Lisbonne 30 août-3 septembre 2011, Paris, Éditions Karthala, 261-276.

Cruz, Gaspar da, 1570. Tractado em que se cõtam muito por estẽso as cousas da China, cõ suas particularidades, e assi do reyno dormuz, cõposto por el. R. padre fray Gaspar da Cruz da ordẽ de sam Domingos, Evora, Casa de André de Burgos. Online: http://purl. pt/22928 (last access: 24 July 2016)

de Rhodes, Alexandre, 1651a. Dictionarium Annnamiticum Lusitanum, et Latinum ope Sacrae Congregationis de Propaganda Fide, Roma, Propaganda Fide.

- 1651b. Linguae Annamiticae seu Tunchinensis Brevis Declaratio. In Dictionarium Annnamiticm Lusitanvm, et Latinum ope Sacrae Congregationis de Propaganda Fide, Roma, Propaganda Fide, 1-31. 
[de Rhodes, Alexandre], 1653. Divers voyages et missions du P. Alexandre de Rhodes en la Chine, \& autres Royaumes de l'Orient, avec son retour en Europe par la Perse \& l'Armenie, Paris, Sebastien et Gabriel Cramoisy.

Faria, Patricia Souza de, 2013. « Os concílios provinciais de Goa: reflexões sobre o impacto da 'Reforma Tridentina' no centro do império asiático português (1567-1606) », Topoi. Revista de História, 14/27, 218-238. On-line: http://www.revistatopoi.org/numeros anteriores/topoi27/AF_TOPOI_27.pdf(Last access: 16/10/2014).

Ferlus, Michel, 1982. "Spirantisation des obstruantes mediales et formation du système consonantique du vietnamien », Cahiers de linguistique - Asie Orientale 11/1, 83-106.

Fernandes, Gonçalo \& Assunção, Carlos, 2014. "Cuôn Từ Điển Tiếng Việt Đầu Tiên (Rome 1651): Đóng Góp Từ Chế Độ Bảo Trợ Của Bồ Đào Nha Đối Với Ngôn Ngữ Học Phương Đông / The first Vietnamese Dictionary (Rome 1651): Contributions of the Portuguese Patronage to the Eastern Linguistics », Journal of Foreign Language Studies 41, Hanoi University, 3-25.

Fonseca, Maria do Céu Brás, 2006. Historiografia linguística portuguesa e Missionária: preposições e posposições no séc. XVII, Lisboa, Colibri.

González Fernández, Fidel, 2011. « La experiencia misionera de Alexandre de Rhodes SJ (1593-1660)», Sudia Missionalia 60, 277-317.

Guilday, Peter, 1921. « The Sacred Congregation de Propaganda Fide (1622-1922) », The Catholic Historical Review 6/4, 478-494.

Guillemin, Alain, 2014. «Alexandre de Rhodes a-t-il inventé le quốc ngữ? Moussons 23, 141-157.

Haudricourt, André-Georges, 2010. «The origin of the peculiarities of the Vietnamese alphabet », Mon-Khmer Studies 39, 89-104. On-line: halshs-00918824v2 (Last access: 16/04/2016).

Jacques, Roland, 1999. De Castro Marim à Faïfo: Naissance et Développement du padroado portugais d'Orient des origines à 1659, Lisboa, Fundação Calouste Gulbenkian.

- 2002. Portuguese Pioneers of Vietnamese Linguistics / Pionniers portugais de la linguistique vietnamienne, Bangkok, Orchid Press.

— 2004. Các nhà truyền giáo Bồ Đáo vá thờ kỳ đầu của Giáo hội công giáo Việt Nam $/$ Les missionnaires portugais et les débuts de l'Eglise catholique au Viêt-nam, 2 vols., Reichstett, France, Định Hướng Tùng Thư.

- 2012. « De 1623 à 1955, options linguistiques des missionaires au Viêt-nam et affirmation de l'identité nationale ", Hugues Didier \& Madalena Larcher (ed.), Pédagogies Missionnaires: Traduire, trasnmettre, transculturer, 32e Colloque du CÉDRIC, Lisbonne 30 août-3 septembre 2011, Paris, Éditions Karthala, 41-51.

Manguin, Pierre-Yves, 1972. Les Portugais sur les côtes du Viêt-nam et du Campâ. Étude sur les routes maritimes et les relations commerciales, d'après les sources portugaises (16 e, 17 e, 18 e siècles), Paris, Publications de l'ÉFEO.

- 1984. Nguyên Anh, Macau et le Portugal. Aspects politiques et commerciaux d'une relation privilégiée, 1773-1802, Paris, Publications de l'ÉFEO.

Maruyama, Toru, 2004. "Linguistic Studies by Portuguese Jesuits in Sixteenth and Seventeenth Century Japan », Otto Zwartjes and Even Hovdhaugen (eds), Missionary Linguistics/Lingüistica misionera: Selected papers from the First International Conference on Missionary Linguistics, Oslo, 13-16 March 2003, Amsterdam, John Benjamins, 141-160.

- 2006. « Pioneering Portuguese linguistic works on sixteenth and seventeenth century Konkani and Japanese », Revista Portuguesa de Humanidades 10.1/2, 137-150.

Maryks, Robert Aleksander, 2010. The Jesuit Order as a synagogue of Jews: Jesuits of Jewish ancestry and purity-of-blood laws in the early Society of Jesus, Leiden / Boston, Brill.

Maspero, Henri, 1912. «Études sur la phonétique historique de la langue annamite: les initiales », Bulletin de l'École française d'Extrême-Orient 12, 1-124. 
Michaud, Alexis, Michel Ferlus, Minh-Châu Nguyễn, 2015. « Strata of standardization: the Phong Nha dialect of Vietnamese (Quảng Bình Province) in historical perspective ", Linguistics of the Tibeto-Burman Area 38.1, 1-37. On-line: halshs-01141389 (Last access: 12/05/2015).

Mourão, Isabel Augusta Tavares, 2005. Portugueses em terras do Dai-Viêt (Cochinchina e Tun Kim), 1615-1660, Macau, Instituto Português do Oriente, Fundação Oriente.

— 2012. « Gaspar do Amaral au Tun Kim: Quelques aspects de la pédagogie missionnaire au Xvire siècle », Hugues Didier \& Madalena Larcher (ed.), Pédagogies Missionnaires: Traduire, trasnmettre, transculturer, 32e Colloque du CEDDIC, Lisbonne 30 août-3 septembre 2011, Paris, Éditions Karthala, 53-61.

Nguyễn, Văn Lợi \& Jerold A. Edmondson, 1998. « Tones and voice quality in modern northern Vietnamese: Instrumental case studies », Mon-Khmer Studies 28, 1-18.

Nguyễn, Đình Hoà, 1997. Vietnamese, Amsterdam/Philadelphia, John Benjamins.

Phan Khoang, [1970] 2001. Việt sử xú Đàng Trong, Hà Nội, Nhà xuất bản văn học.

Phan, Peter C., 1998. Mission and Catechesis: Alexandre de Rhodes and Inculturation in Seventeenth-Century Vietnam, Maryknoll / New York, Orbis Books.

[Pina, Francisco de], ca. 1745a [ante 1623]. Manuductio ad linguam Tunchinensem, Biblioteca da Ajuda, Lisboa, manuscript, collection "Jesuítas na Ásia", Codex Ms. 49-VI-8, 313r-323v.

- ca. 1745b [ca, 1623]. Pax Christi, Biblioteca da Ajuda, Lisboa, manuscript, collection "Jesuítas na Ásia", Codex Ms. 49/V/7, 413r-416r.

Rego, António da Silva, 1940. O Padroado Português do Oriente: Esboço Histórico, Lisboa, Agência Geral das Colónias.

Ribeiro, Madalena, 2001. "The Japanese diaspora in the seventeenth century according to Jesuit sources. Bulletin of Portuguese - Japanese Studies 3, 53-83.

Rodrigues, Francisco, 1917. A formação intelectual do Jesuita: Leis e Factos, Porto, Livraria Magalhães \& Moniz.

- 1931-1950. História da Companhia de Jesus na Assistência de Portugal, 7 tomes, Porto, Livraria Apostolado da Imprensa.

Rodrigues, João, 1604[-1608]. Arte da Lingoa de Japam. Nangasaqui: Collegio de Iapão da Companhia de Iesu.

Rodrigues, João, 1993 [1620]. Arte Breve da Lingoa Iapoa. Fac-simile do original existente na Biblioteca Nacional da Ajuda, Lisboa, acompanhado da transcrição e tradução japonesa de Hino Hiroshi, Tokyo, Shin-Jinbutsu-Ôrai-Sha.

Sena, Tereza, 2014. " O Padroado Português no Extremo Oriente », Miguel Castelo-Branco (ed.), Portugal-China: 500 anos, Lisboa, Biblioteca Nacional de Portugal, 91-98.

Souza, Teotónio R. de, 2008. "O Padroado português do Oriente visto da Índia: instrumentalização política da religião ", Revista Lusófona de Ciência das Religiões 13/14, 413-430.

Spear, Richard L., 1975. "Introduction », Diego Collado's Grammar of the Japanese language. International Studies, East Asian Series Research Publication, number 9, Lawrence, Center for East Asian Studies (CEAS), The University of Kansas, 1-30.

Taylor, Keith Weller \& John K. Whitmore, 1995. Essays Into Vietnamese Pasts, Ithaca, N.Y., Southeast Asia Program, Cornell University.

Teixeira, Pe. Manuel, 1996. A Igreja em Cantão, Macau, Instituto Cultural de Macau.

Thompson, Laurence C., 1987. A Vietnamese Reference Grammar, Honolulu, University of Hawai'i Press.

Wernz, Franz Xaver, Ludwig Schmitt, \& J.B Goetstouwers (eds), 1950. Synopsis historiae Societatis Jesu. Lovanii, Typis ad Sancti Alphonsi.

Zwartjes, Otto, 2011. Portuguese Missionary Grammars in Asia, Africa and Brazil, 15501800. Amsterdam \& Philadelphia, John Benjamins. 